Anatolian Journal of Education

\title{
THE EFFECT OF GROUP INVESTIGATION (GI) LEARNING MODEL ON THE STUDENT PROBLEM SOLVING ABILITY AND STUDENTS ACADEMIC ACHIEVEMENT ON THE DIGESTIVE SYSTEM MATERIAL FOR BIOLOGY STUDENTS
}

\author{
Markus Iyus Supiandi
}

College of Teacher Training and Education (STKIP) Persada Khatulistiwa Sintang, West Borneo, Indonesia, msupiandi@gmail.com

\section{Benediktus Ege}

College of Teacher Training and Education (STKIP) Persada Khatulistiwa Sintang, West Borneo, Indonesia,ama_tamo@yahoo.com

\begin{abstract}
This research was carried out to analyze the effect of Group Investigation (GI) model on the student problem solving ability and students academic achievement on the digestive system material for students grade $8^{\text {th }}$ junior high school 2 Belimbing Hulu. In this study we used quasi experimental design according to the quantitative research methods, pretest-posttest using rubric to test the effect of Group Investigation (GI) learning model on the student problem solving ability and students academic achievement. The result of this research showed that the Group Investigation (GI) learning model improved the student problem solving ability and students academic achievement.. The increase of problem solving ability of students treated with Group Investigation (GI) model was $68.65 \%$ and the students' cognitive learning result was $47.73 \%$ higher than the conventional learning model of $38.37 \%$ for problem solving skills and $23.60 \%$ for cognitive learning outcomes. Based on the research results it can be concluded that Group Investigation (GI) learning model has the potential to improve the student problem solving ability and students academic achievement. It is recommended that teachers implement Group Investigation (GI) learning model in schools consistently because it improves effectively on the student problem solving ability and students academic achievement.
\end{abstract}

Key Words: Group investigation, Problem solving ability, Acaedmic achievement, Biology, Digestive system. 


\section{Introduction}

Education was a set of processes to develop student competence related to the norm and culture values in society. Education system will give a good way for the future development of a certain country for the 21st century. Among the various subjects studied in the educational process, biology subjects are one of the important subjects to be mastered by students (Asele et al, 2016). Wood (2002) and Erdogan et al (2012) said that biology learning aimed to equip the students with the concepts of biology that could be understood and applied in their lives in order to improve the ability to manage nature with a sense of responsibility and improve the ability to cope with change in society.

Science classroom is the study of objects and problems of natural phenomena. All objects and natural phenomena are the object of study science classroom. Modern theory, the learning process does not depend on the existence of the teacher as the manager of the teaching and learning process. The learning process actually is essentially an interaction between students with the object being studied. Based on this, the role of sources and learning media cannot be excluded in the biology learning process.

Biology is a manifestation of student interaction learning process with objects consisting of objects, events, processes, and products (Djohar, 1987). Biology is more common in science education, so the consequences in learning should give lessons to the subject of learning to interact with the object of learning independently, so as to explore and find the concept. The Biology as the science classroom was interaction between subjects and the objects of learning. These interactions provide opportunities for students to practice learning and understand how to learn, enrich the rational potential of thinking, skills, and personality as well as recognizing biological issues and their assessment.

But the reality is often encountered that teachers in implementing learning based on less varied learning. Although the curriculum has been developed by every school, the competencies of the teachers have not met the needs of students yet. For example learning processes focus only on the ultimate goal, but ignore the process of what happens to the students mind. Therefore, students do not understand how they learn. In relation to the students' understanding of how he or she is studying, it is necessary to empower the thinking skills.

To face the 21 st century as the information era, the world need a human resource with a good quality in the way they think. Therefore, we need special attention to the learning process. Paramata (2014) explains that the challenge of the 21st century is how to make students pass their critical thinking and creative thinking in solving problems. 
The ability to solve problems is one of the benchmarks of a person's quality in this modern era. Problem solving in science learning has become a major subject in the investigation. In addition, problem-solving activities help students to construct new knowledge and facilitate science learning (Mukhopadhyay, 2013). To face the challenges of the 21 st century, it is better for teachers to prepare students to become an investigator, problem solver, critical and creative thinker (Barell, 2010). Furthermore Greenstein states that qualified person in the 21 st century is person who has life skills, one of them is the ability to solve problems.

The preliminary observations that have been done in junior high school 2 Belimbing Hulu show that the empowerment of problem solving ability is not optimal yet. The material delivered in the science classroom still focus on the theory. It needs to use factual problems that are real in the daily life of students. Biology is closely related to find out information and to develop the information, so it needs to overcome the problems in the learning process. On the contrary, teachers only focus on questions. In the learning process, the teacher needs to add a lot of phenomenon which relate to find solution. It has not lead students to solve problem that requires students to be able to formulate problems, formulate hypotheses, collect data, test hypotheses, draw conclusions, and recommend problem solving.

In learning science, besides understanding knowledge and applying the material to new things, students also need to develop their problem-solving skills in order to form scientific thinking in their daily life (Elvan, 2010). To teach the development of students' problem solving abilities, a teacher must also have optimal problem-solving skills. The research shows that the students fail to fully master the concept so that the students are unable to solve the problem. Therefore, it affects the students' academic achievements.

The students academic achievements showing 71,45 stay at good position. The standard minimize at juniar high school 2 Belimbing Hulu was 75. From these case there were a lot of students fail to reach the standard minimize score, at least 28,55 on the students academic achievements.

The factors that cause low cognitive learning outcomes of students are: 1) the learning process in schools still uses lecturing method so it cannot develop the thinking potential of students to solve problems that can impact on low cognitive learning outcomes; 2) teachers only provide a glimpse of information on a certain subject and still use unsuitable method in learning process so it causes passive learning; 3) the material delivered in the biology learning processes still focus on the theory. It needs to use factual problems that are real in the daily life of students

The solution to overcome the problem above is using the learning model which develop student critical thinking. The learning model called Group Investigation (GI), this model needs students having a good communication skill and group skill process (Nurhadi, et al, 2004). According to Sharan and Sharan (1992), Group Investigation (GI), was a cooperative learning integrated the students achievements with the 
interaction of communication. It was design for students ability to define the problem, explore problems, collect the relevance data, enrich ad try out the hypothesis. This learning model teaches students to build their ability to think independently and critically and to solve a problem in a group.

According to Slavin (2010), steps in applying the Group Investigation (GI) learning modelare as follows: 1) Grouping and Choosing topic, 2) Planning, 3) Investigation, 4) Organizing, 5) Presentation, 6) Evaluation. Each steps needs students to have a good critical thinking to solve problems. Group Investigation (GI) learning model is a cooperative learning model because it combines the cooperative principal and constructivism-based learning. Group Investigation (GI) learning model was a structure and organize representation reality (Richey, 1986).

Group Investigation (GI) learning model can help teachers to attribute the teaching materials to the students' real environment, to encourage the students to create a connection between the teaching material and student's real environment and to encourage the students to apply their knowledge.

\section{Methodology}

This research uses quasi-experimental design. The research's design is nonequivalent pratest-posttest control group design. The sample of this research is Class VIII A students as the experimental group and Class VIII B students as the control group. The sampling tecnique used is simple random sampling that was done randomly to students with heterogenous academic ability. Data collection techniques using measurement techniques include essay test in the form of description questions that are used to obtain data problem solving ability and student academic achievement. The data of problem solving ability and cognitive learning result were tested normality with One Sample Kolmogorov Smirnov and homogeneity test with Levene Test of Equality of Error Variances. Hypothesis testing with Single Anova test assisted with SPSS version 23 program.

\section{Findings}

The research data were analyzed by using anova followed by pretest and posttest results on the students' problem solving ability are presented in Table 1.

Table 1

The result of the Anova test on students problem solving ability

\begin{tabular}{lccccc}
\hline Source & $\begin{array}{c}\text { Type III Sum } \\
\text { of Squares }\end{array}$ & Df & $\begin{array}{c}\text { Mean } \\
\text { Square }\end{array}$ & \multicolumn{1}{c}{ F } & \multicolumn{1}{c}{ Sig. } \\
\hline Corrected Model & $2132,896^{\mathrm{a}}$ & 2 & 1066,448 & 22,703 &, 000 \\
Intercept & 6177,360 & 1 & 6177,360 & 131,509 &, 000 \\
Problem Solving & 532,896 & 1 & 532,896 & 11,345 &, 002 \\
Ability & & & & &
\end{tabular}




\begin{tabular}{lccrrr} 
Model & 1595,462 & 1 & 1595,462 & 33,966 &, 000 \\
Error & 1550,104 & 33 & 46,973 & & \\
Total & 166092,000 & 36 & & & \\
Corrected Total & 3683,000 & 35 & & & \\
\hline
\end{tabular}

The calculation show that the significance value was less than 0,05 which was equal to 0,000 . This means that the null hypothesis is rejected and the research hypothesis is accepted. Thus, there is influence of learning model to problem solving ability. Further testing is then performed by using Least Significant Difference (LSD), which was conducted to determine the learning model that provide the highest influence in improving the problem solving ability. Table 2 shows test results of the influence of the learning model on students' problem solving abilities.

Table 2

\begin{tabular}{|c|c|c|c|c|c|c|}
\hline No & Learning Model & Pretest & Posttest & Difference & Cor & $\begin{array}{l}\text { Notation } \\
\text { LSD }\end{array}$ \\
\hline 1 & $\begin{array}{l}\text { Group } \\
\text { Investigation }\end{array}$ & 43,777 & 73,833 & 30,056 & 73,824 & $\mathrm{a}$ \\
\hline 2 & Conventional & 43,722 & 60,500 & 16,778 & 60,509 & $\mathrm{~b}$ \\
\hline
\end{tabular}

In Table 2 shown the average of problem solving ability from each learning model. The average rate of the corrected of the two learning model, showed that the result of the problem solving ability with conventional model have declimed by an average of 60,509 and the results of the problem solving ability by Group Investigation (GI) has an average of corrected amounting to 73,824 . Statistically it shows the differences in the rate of the problem solving ability that occur in both learning model showing significant differences. The research data were analyzed by using anova followed by pretest and posttest results on the students' academic achievement are presented in Table 3.

Table 3

The result of the Anacova test on students academic achievement

\begin{tabular}{lcrcrc}
\hline & Type III Sum of & & & & \\
Source & Squares & df & Mean Square & \multicolumn{1}{c}{ F } & Sig. \\
\hline Corrected Model & $3535,804^{\mathrm{a}}$ & 2 & 1767,902 & 57,000 &, 000 \\
Intercept & 9283,822 & 1 & 9283,822 & 299,325 &, 000 \\
Academic Achievement & 591,349 & 1 & 591,349 & 19,066 &, 000 \\
Learning Model & 2804,356 & 1 & 2804,356 & 90,417 &, 000 \\
Error & 1954,000 & 33 & 31,016 & & \\
Total & 297491,319 & 36 & & & \\
Corrected Total & 5489,804 & 35 & & & \\
\hline
\end{tabular}

The calculation show that the significance value was less than 0,05 which was equal to 0,000 . This means that the null hypothesis is rejected and the research hypothesis is accepted. Thus, there is influence of learning model to students academic achievement. Further testing is then performed by using Least Significant Difference (LSD), which was conducted to determine the learning model that provide the highest influence in 
improving the students academic achievement. Table 4 shows test results of the influence of the learning model on students' academic achievement.

Table 4

The comparison of mean score learning model on the students academic achievement

\begin{tabular}{|c|c|c|c|c|c|c|}
\hline No & Learning Model & Pretest & Posttest & Difference & Cor & $\begin{array}{l}\text { Notation } \\
\text { LSD }\end{array}$ \\
\hline 1 & $\begin{array}{l}\text { Group } \\
\text { Investigation }\end{array}$ & 49,545 & 73,194 & 23,649 & 73,042 & A \\
\hline 2 & Conventional & 48,409 & 59,835 & 11,426 & 59,988 & b \\
\hline
\end{tabular}

Table 4 shows the corrected mean of learning model on the students' academic achievements of Group Investigation (GI) are different from conventional learning model. The average corrected score of the two learning models shows that students' academic achievement with conventional learning models have corrected averages of 59.988 and students' academic achievement with Group Investigation learning model (GI) have an average corrected value of 73.042. Statistically shows the difference of value of students' academic achievement between Group Investigation (GI) learning model and conventional learning model.

\section{Discussion}

The results of the research shows that Group Investigation (GI) learning model is measured pretest and posttest based. The results of problem solving ability and students academic achievement pretest and posttest based indicate that the learning model has an effect on the problem solving ability and students academic achievement. This is indicated by the probability of learning model 0.000 or less than $0.05(\mathrm{p}<0.05)$ so that the null hypothesis is rejected and the research hypothesis is accepted. Students study using Group Investigation (GI) learning models having a higher problem solving ability and students academic achievement than conventional learning model.

The average students' problem solving ability with Group Investigation (GI) learning model was 73,824 higher than students' conventional learning model with corrected average of 60,509 . Meanwhile, the corrected average students academic achievement with Group Investigation (GI) learning model of 73.042 higher than conventional learning model with an average 59.988 .

Students' ability in problem solving through Group Investigation (GI) learning model $68.65 \%$ is higher than conventional instruction learning model with $38.37 \%$. The students' academic achievement through Group Investigation (GI) learning model $47.73 \%$ is higher than conventional instruction learning model with $23.60 \%$. It is proved by the results of several previous studies (Johnson \& Johnson, 2005; Tanel \& Erol, 2008; Moore, 2008; Sahin, 2010) suggesting that cooperative learning fosters long-term achievement rather than individual learning. Furthermore (Johnson \& Johnson, 2008; 
Moore, 2008; Tanel \& Erol, 2008; Web, 2008; Sahin, 2010; Slavin, 2011) stated that cooperative learning produces long term learning outcomes rather than conventional learning.

The result of the study proved the Group Investigation (GI) learning model implemented in the science classroom is a cooperative learning model. According to Ibrahim (2000) cooperative learning is a learning strategy that helps students learn the academic content and social relationships. Kagan (1992) states that cooperative learning as an instructional strategy that involves cooperative student interaction in studying a topic as an integral part of the learning process. Furthermore Jacob (1999) suggests that cooperative learning is an instructional method in which students in small groups work together and help each other in solving problems.

Meanwhile, Group Investigation (GI) learning model stressed on students participation in defining topics, investigating problems, analyzing findings and conveying findings. It can increase students' activity and participation to find the information relating to the material being studied by using the various learning resources such as relevant learning books or other sources. It was agreed by Arifin and Afandi (2015) that the Group Investigation (GI) model is a lesson in which students are involved since the planning, both in determining the topic/subtopic and the way for investigative learning and this model requires students to have good communication skills as well as train students in solving a problem in the group.

The Group Investigation learning model (GI) stages affected the students ability in problem solving. Grouping and choosing topic leads students to identify problem in their daily life. As Setiawan (2006) said that the Group Investigation (GI) model adopts a model that applies in the community, especially regarding community members to the process of social mechanism and a series of social agreements. Students discuss with the group to determine the topic of the problem that is happening around their life. At the planning stage it can encourage students to be more tolerant and cooperate among group members because students divide the group tasks of each group member.

The investigation was the main essence of Group Investigation learning model (GI) because students collected various facts to analyze the problems discussed. Learning sources taken from relevant books, internet, published, electronics media and trusted speakers. At the moment all sources collected the group members transfer their idea others, discussion, clarification and analyze all ideas in their groups. The critical thinking ability formed by doing observation. Observation can increase the students' critical thinking ability because they can take the suggestion from others references. According to Depdiknas (2005), teachers need to help students to find information, and take a role as the main learning resource, that can create social environment with democratic and science characters.

Organization stage is a stage in which the member of the group join together to finish the learning report. Every member determines the main message of the topic under study. In this phase, students' creative thinking ability is to determine the observation 
result and decision-making. The purpose of this discussion is to make a final decision used for reporting and presenting the result of investigation. The report of investigation result must be reviewed in terms of theoritical framework so it can be accapted scientifically. In this part teachers play as the facilitator that leads grouping process. As Joyce \& Weil (1980) said teachers plays as the academic advisor.

The presentation stage is performed after the group finishes the investigation and draws conclusions, then it is followed by presenting or conveying answers to all class members. In this phase, critical thinking skills and problem solving skills is to provide opinions, to determine the outcome of the presentation and to evaluate the decision. In this stage we can form the critical thinking ability and problem solving ability in the complexes, when the students transform their knowledge and information with questioning, answering, giving opinion and disagreeing. In this part, all the groups present an interesting presentation of the various topics that have been studied so that all students can achieve a broad perspective on the topic. Sarmawan said that it is a motivation to force the students being active in the learning process from the first stage until the final stage (Sarmawan, 2010).

Evaluation stage is a stage in which teacher gives sufficient reviews and explanations as a clarification of the student's answers. Both students and teachers have to evaluate each group's contribution of a whole work. The applied evaluation can be either individual or group assessment (Trianto, 2007). In addition, the evaluation stage of Group Investigation (GI) can be used as a reflection activity. Teachers ask the students to rewrite their experiences and new knowledge, so that this activity positively impacts students' memory on the subject matter which affects indirectly students' academic achievement. As constructivist said, the discovery of knowledge which is constructed by the students themselves will be attached to the memory of students in a long period.

As Arends (2008) said learning model can help students get new knowledge, learning various skill and responding the recent information. Group Investigation (GI) not only conduct students active in learning to make a meaningful learning (Dahar, 1988) but also giving students opportunity for intreaction between students and teachers. It makes the feeling of learning process dedicate both teachers and students have responsible. As Munandar (1999) said, a child who is given an autonomy will give internal motivation, less learning constraint and better learning concept.

\section{Conclusion and Suggestions}

There is an impact of the application of Group Investigation (GI) model on the problem solving ability and cognitive learning outcomes in class VIII students of junior high school 2 Belimbing Hulu. Based on Least Significant Difference (LSD) test, the students' average corrected score of problem solving ability using Group Investigation (GI) is 73,824 higher than conventional learning model of 60,509. Meanwhile, in Least 
Significant Difference (LSD) test, the average corrected score of cognitive learning outcomes using Group Investigation (GI) model is 73,042 higher than conventional learning model of 59,988. The improvement of problem solving skills and cognitive learning outcomes of students using Group Investigation (GI) model is $68.65 \%$ and $47.73 \%$ higher than the conventional learning model of $38.37 \%$ and $23.60 \%$. Based on the results of this study, the researcher suggested teachers to apply Group Investigation (GI) model consistently because it has been proven through its successful improvement on the students' problem solving ability and students' cognitive learning outcomes.

\section{References}

A Sele, Y., Corebima, D., Indriwati S.E. (2016). The Analysis of the Theaching Habit Effect Based on Conventional Learning in Empowering Metacognitive Skill and Critical Thinking Skill of Senior High School Students in Malang, Indonesia. International Journal of Academic Research and Development Vol 1; Issue 5; May 2016; Page 64-69.

Arends, R. (2008). Learning to Teach. Sixth Edition. New York: McGrawHill.

Arifin, Z. \& Afandi, Y. (2015). Pengaruh Model Pembelajaran Kooperatif Tipe Investigasi Kelompok (Group Investigation) dan Strategi Student Team Achievement Division (STAD) terhadap Keterampilan Proses dan Hasil Belajar Akuntansi Siswa SMK Di Kota Kediri [The Influence of Cooperative Learning Model of Group Investigation Type and Student Team Achievement Division (STAD) Strategy To The Process Skill and Students Learning Achievement Accounting Subject Of The Vocational High School Students at Kediri City]. Jurnal Penelitian Pendidikan. Volume 02 No.01, 10-25. Retrieved 18 April, 2017 from http://lp2m.unpkediri.ac.id.

Barell, J. (2010). Excerpts from "Problem Based Learning: The Foundation for 21st $\begin{array}{lllll}\text { CenturySkills. } & \text { Retrieved } & 1 & \text { April, } & 2017\end{array}$ http://www.morecuriousminds.com/docs/21stCSummary2.pdf.

Dahar, R. W. (1988). Teori-teori Belajar [Theories of Learning]. Jakarta: Erlangga.

Depdiknas. (2005). Panduan Pengembangan Model Pembelajaran Berbasis Kompetensi [Development Guidelines of Competence Based Learning Model]. Jakarta: Direktorat PPTK dan KPT Dirjen Dikti.

Djohar. (1987). Peningkatan Proses Belajar Mengajar Sains Melalui Pemanfaatan Sumber Belajar [Upgrading To The Teaching and Learning Process By Using Learning Source]. Jurnal Kependidikan Yogyakarta: IKIP Yogyakarta 2(17).

Elvan. (2010). Effects of Problem Solving Method on Science Process Skills and Academic Achievement. Retrieved 1 May, 2017 from http://www.academia.edu/1072151/Effect_of_Problem_Solving_Method_on_Scie nce_Process_Skills_and_Academic_Achievement.

Erdogan, M.; Bahar, M.; Usak, M. (2012). Environmental Education in High School 9th-12th Biology Course Curricula Started to be Implemented in 2007, Educational Sciences: Theory \& Practice. 12(3):2230-2235. 
Greenstein, L. (2012). Assessing $21^{\text {st }}$ Century Skill: A Guide to Evaluating Mastery and Authentic Learning. America: Corwin A Sage Company.

Ibrahim, M. (2000). Pembelajaran Kooperatif [Cooperative Learning]. Surabaya: University Press.

Jacob, E. (1999). Cooperative Learning In Context: An Educational Innovation in Everyday Classroom. Albany: State University of New York Press.

Johnson, D. W., \& Johnson, R. T. (2005). New Developments in Social Interdependence Theory. Genetic, Social, \& General Psychology Monographs, 131 (4), 285-358. http://dx.doi.org/10.3200/MONO.131.4.285-358.

Johnson, D. W., \& Johnson, R. T. (2008). Social Interdependence Theory and Cooperative Learning: The Teacher's Role. In Gillies, R. M., Ashman, A. \& Terwel, J. (Eds). Teacher's Role in Implementing Cooperative Learning in the Classroom (pp.9-37). New York, U.S.A: Springer. http://dx.doi.org/10.1007/9780-387-70892-8_1.

Joyce, B., \& Weil, M. (1980). Models of Teaching (Second Edition). Englewood Cliffs, New Jersey: Prentice-Hall, Inc.

Kagan, S. (1992). Cooperative Learning. San Juan Capistrano: Kagan Cooperative Learning.

Moore, K. D. (2008). Effective instructional strategies: From theory to practice. Thousand Oaks, CA: Sage Publications.

Mukhopadhyay, R . (2013). Problem Solving In Science Learning-Some Important Considerations of a Teacher. Retrieved 26 April, 2017 from http://www.iosrjournals.org/iosrjhss/papers/Vol8-issue6/C0862125.pdf.

Munandar. (1999). Mengembangkan Bakat dan Kreativitas Anak Sekolah [Developing Talent and Creativity of Student]. Jakarta: Rineka Cipta.

Nurhadi at al. (2004). Pembelajaran Kontekstual (Contextual teaching and learning/CTL) dan Penerapannya dalam KBK [Contextual Teaching and Learning and Its Implementation on Competence Based Curriculum]. Malang: UM Press.

Paramata, D. D., Paramata Y., Uno D. W. (2014). Model Pembelajaran IPA Terpadu Berorientasi Multiple Intelligences dan Pemberdayaan Metakognisi Siswa melalui Integrasi Kurikulum di SMP [Integrated Natural Science Learning Model Oriented to Multiple Intelligences and Empowering Students Metacognition Through Curriculum Integration]. Prosiding Seminar Nasional Kimia. Surabaya: FMIPA Universitas Negeri Surabaya.

Richey. (1986). The Theoritical and Conceptual Bases of Instructional Design. New York: Nichols Publishing.

Sahin, A. (2010). Effects of Jigsaw III technique on achievement in written expression. Asia Pacific Educ. Rev, Education Research Institute, Seoul National University, Seoul, Korea. http://dx.doi.org/10.1007/s12564-010-9135-8. 
Sarmawan. (2010). Analisis Data Penelitian Kualitatif(Pemahaman Filosofis ke Arah Penguasaan Model Aplikasi) [Analysis of Qualitative Research Data (Phylosophy Understanding To The Application Mastering Model)]. Jakarta: Raja Gafindo Persada.

Setiawan. (2006). Model Pembelajaran Matematika Dengan Pendekatan Investigasi [Mathematics Learning Model With Investigation Approach]. Yogyakarta: Depdiknas PPPG Matematika.

Sharan, Y. \& Sharan, S. (1992). Expanding Cooperative Learning Through Group Investigation. New York: Teachers' Collage Press.

Slavin, R. E. (2010). Cooperative Learning Teori, Riset, dan Praktik [Cooperative Learning Theory, Research, and Practice]. Bandung: Nusa Media.

Slavin, R. E. (2011). Instruction Based on Cooperative Learning. In R. E. Mayer \& P. A. Alexander (Eds), Handbook of Research on Learning and Instruction (pp.344360). New York: Taylor \& Francis.

Tanel, Z. \& Erol, M. (2008). Effect of Cooperative Learning on Instructing Magnetism: Analysis of an Experimental Teaching Sequence. American Journal of Physics and Education, 2 (2), 124-136.

Trianto. (2007). Model-model Pembelajaran Inovatif Berorientasi Konstruktivisme [Innovative Learning Models Oriented to Constructiveness]. Jakarta: Prestasi Pustaka.

Webb, N. M. (2008). Learning in Small Groups. In T. L. Good (Ed), 21 st Century education: A reference handbook (pp. 203-211). Los Angeles: Sage.

Wood, W. B. (2002). Advanced High School Biology In An Era Of Rapid Change: A Summary of the Biology Panel Report from the NRC Committe on Programs for Advanced Study of Mathematics and Science in American High School, Cell Biology Education. 1:123-127. 